\title{
Urbanization Negatively Affects the Species Composition of Native Ladybirds in Central Europe
}

\author{
Jiři Skuhrovec*, Alois Honek and Zdenka Martinkova \\ Group Function of Invertebrate and Plant Biodiversity in Agro-Ecosystems, Crop Research Institute, Prague, Czechia
}

We evaluated the differences in frequency (percentage of sampling sessions where the species was recorded) and abundance (mean number of individuals per 100 sweeps) of native species of ladybirds (Coleoptera: Coccinellidae) in the center of Prague, Central Europe, and in its outskirts. Between 2016 and 2019, coccinellids were sampled on Tilia stands using a standardized sweeping method. Twenty-one species were identified in the total sample of 2,761 adults that were collected in 504 sampling sessions. Species richness was significantly higher in the outskirts than in the center, where seven species were absent and two species were found only once. In contrast, only five species were more abundant in the center than in the outskirts. Communities of native coccinellids

OPEN ACCESS

Edited by:

Danny Haelewaters,

Ghent University, Belgium

Reviewed by:

António Onofre Soares,

University of the Azores, Portugal

Thomas Martin

Operation Wallacea, United Kingdom

${ }^{*}$ Correspondence:

Jiř Skuhrovec

jirislavskuhrovec@gmail.com

Specialty section:

This article was submitted to

Global Biodiversity Threats,

a section of the journal

Frontiers in Conservation Science

Received: 15 July 2021 Accepted: 30 November 2021 Published: 20 December 2021

Citation:

Skuhrovec J, Honek A and Martinkova Z (2021) Urbanization

Negatively Affects the Species Composition of Native Ladybirds in

Central Europe.

Front. Conserv. Sci. 2:741899.

doi: 10.3389/fcosc.2021.741899 were poorer in species, and most species were less abundant in the center than in the outskirts.

Keywords: urban habitats, invasive, ladybirds, species richness, abundance

\section{INTRODUCTION}

The decline in abundance and diversity of insect communities is a current topic of concern to society as a whole (e.g., Hallmann et al., 2017; Sánchez-Bayo and Wyckhuys, 2019). This is because some factors in this process, e.g., climate change and habitat loss, are influenced by human activity (Ceballos et al., 2017; Meyer et al., 2020; Milanovic et al., 2021; Wagner et al., 2021). An important factor threatening insects is urbanization (McGlynn et al., 2019), which increases the area of urban settlements at the expense of agricultural land, forest, and other land uses (Goddard et al., 2010; Jones and Leather, 2012; Rocha et al., 2018; Milanovic et al., 2021). The effect of urbanization has been well-studied on ladybirds (Coleoptera, Coccinellidae) (Honek et al., 2021; Sloggett, 2021). This family includes a number of predatory species feeding mainly on aphids (Hodek et al., 2012). The aphidophagous species of coccinellids are easily identifiable (Jouveau et al., 2018), they can be picked up by sampling methods, which allows their research in the urban environment where they are assembled mainly on trees infested with aphid populations (Honek et al., 2017; Rocha et al., 2018). In addition to the availability of prey, coccinellids species are also affected by the microclimate, the possibility of immigration from source populations living in the city surroundings, and interactions with other species of the guild of aphid predators (Korányi et al., 2021; Sloggett, 2021). Therefore, coccinellids are a suitable subject for study into the effect of urbanization on insects. Covering urban areas with impervious surfaces, such as buildings and paved or tarmac roads, has a negative effect on the quality of habitats: urban green spaces (where coccinellid prey and its host plants can persist) is fragmented into small discontinuous islands (Rocha et al., 2018; Sloggett, 2021). Urbanization of large areas can thus negatively affect the presence and abundance of coccinellids in the area by reducing the availability of breeding sites and 
increasing the need for migration abilities of coccinellids to enable displacement from undisturbed habitats of the city surroundings to the center or between green islands in urban areas (Sloggett, 2021). Fragmentation of green spaces may cause a shortage of food and extinction or emigration of the local population of coccinellids.

Each city differs in both the size of its urbanized area and the expansion and degree of fragmentation of its urban green spaces (Cepelová et al., 2017; Greyvenstein et al., 2021). To study the effects of these differences, it is necessary to compare coccinellid populations in centers and outskirts for a number of different sized cities. Here, we report the results of a study investigating coccinellid occurrence and abundance in Prague, a city of $\sim 1$ million inhabitants located in the temperate zone of Central Europe. We used the results of a four-year study (2016-2019) of coccinellid communities on lime trees (Tilia spp.) carried out in this city, which enabled evaluation of differences in composition and abundance of native species in the outskirts and center. As the known negative impact of urbanization, we hypothesize that in the center of Prague, there will be lower diversity and abundance of coccinellids than in the outskirts.

\section{MATERIALS AND METHODS}

\section{Sampling}

Between 2016-2019, coccinellids were sampled in two areas, henceforth called "outskirts" and "center," situated at a distance of $\sim 10 \mathrm{~km}$ in the western part of Prague, Central Europe. The difference in urbanization at the outskirts and center areas was quantified as the percentage of the area surrounding the sampling sites (a circle of $500 \mathrm{~m}$ radius centered at each sampling site) covered by impervious surfaces (buildings, streets, parking places, etc.) (Honek et al., 2018b). This value was $39 \pm 3.0 \%$ in the outskirts and $71 \pm 5.6 \%$ in the center. This was determined using maps available at https://en.mapy. cz. Coccinellids were sampled at 14 localities (henceforth called sites), eight in the outskirts, and six in the center (Figure 1). At each site was a group of $\geq 5$ lime trees (Tilia cordata Mill. and/or Tilia platyphyllos Scop.). Coccinellids were sampled on these groups of lime trees in regular intervals (Table 1). Sampling at a particular site and on a particular date is henceforth called a "sampling session." In each sampling session, the coccinellids were collected of all lime trees present at the site. The result of the sampling session was therefore a mixed set of coccinellids from all lime trees growing at the site, henceforth called sample. The total number of samples collected is shown in Table 2. Sampling from the canopy up to a height of c. $3 \mathrm{~m}$ was standardized by using a standard sweep net $(35-\mathrm{cm}$ diameter, $140-\mathrm{cm}$ handle) operated by J.S. (center) and A.H. (outskirts). Sampling (80-200 sweeps at each site) occurred between 08.00 and $18.00 \mathrm{~h}$ on sunny and calm days. The coccinellid adults were identified regarding species (for illustration see Nedvěd, 2020) immediately and were released at the site.

\section{Describing Species Composition}

Analyses of results from sampling sessions included samples that consisted of $\geq 1$ native coccinellid adult. The presence of coccinellid species was described by two characteristics: (i) the presence/absence of the species in the sample and (ii) the abundance of species, which was the number of individuals recalculated per 100 sweeps. Characteristic (i) was used as a standard to evaluate the differences in species occurrence between outskirts and centers, and characteristic (ii) was used to study the intraspecific differences in population density between the outskirts and centers. The occurrence of a particular species in an area (outskirts or center) was described as the percentage of sampling sessions with a positive characteristic value (i) and its abundance as the average of the characteristic values (ii). Characteristics (i) and (ii) were correlated, and a significant linear relationship was found between the two characteristics (Figure 2).

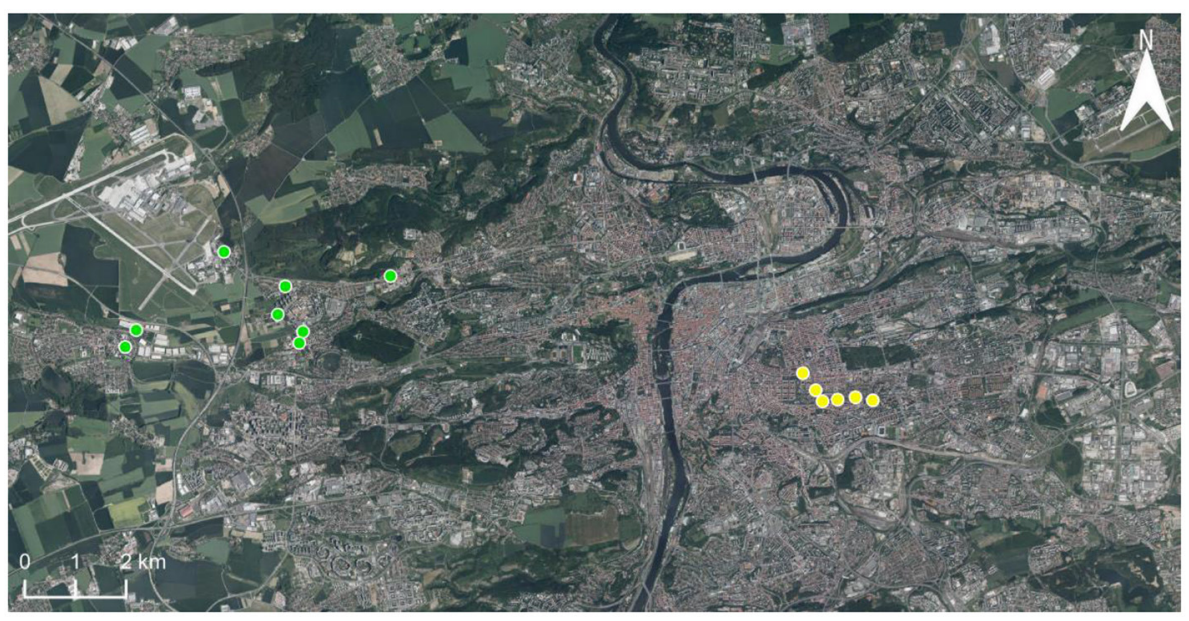

FIGURE 1 | The geographic position of sampling sites in Prague outskirts (8 sites, green dots) and center (6 sites, yellow dots). 
TABLE 1 | Dates of sampling in the outskirts and in the center.

\begin{tabular}{|c|c|c|}
\hline \multirow[b]{2}{*}{ Year } & \multicolumn{2}{|c|}{ Date of sampling } \\
\hline & Outskirts & Center \\
\hline 2016 & $\begin{array}{l}\text { 10-May; 20-May; 06-Jun; 21-Jun; 04-Jul; 12-Jul; 22-Jul; 27-Jul; } \\
\text { 08-Aug; 22-Aug; 24-Aug; 05-Sep; 21-Sep; 05-Oct; 15-Oct; 27-Oct; } \\
\text { 07-Nov }\end{array}$ & $\begin{array}{l}\text { 06-May; 11-May; 20-May; 30-May; 07-Jun; 13-Jun; 21-Jun; 28-Jun; } \\
\text { 11-Jul; 18-Jul; 25-Jul; 04-Aug; 15-Aug; 24-Aug; 08-Sep; 14-Sep; } \\
\text { 27-Sep; 07-Oct; 24-Oct }\end{array}$ \\
\hline 2017 & $\begin{array}{l}\text { 10-May; 16-May; 23-May; 29-May; 08-Jun; 14-Jun; 21-Jun; 28-Jun; } \\
\text { 07-Jul; 17-Jul; 25-Jul; 04-Aug;15-Aug; 23-Aug; 30-Aug; 06-Sep; } \\
\text { 11-Sep; 27-Sep; 04-Oct; 17-Oct }\end{array}$ & $\begin{array}{l}\text { 25-Apr; 03-May; 10-May; 17-May; 26-May; 05-Jun; 13-Jun; 22-Jun; } \\
\text { 30-Jun; 10-Jul; 16-Jul; 21-Jul; 31-Jul; 07-Aug; 14-Aug; 22-Aug; } \\
\text { 30-Aug; 08-Sep; 18-Sep; 27-Sep; 13-Oct; 26-Oct }\end{array}$ \\
\hline 2018 & $\begin{array}{l}\text { 09-May; 18-May; 24-May; 31-May; 06-Jun; 11-Jun; 20-Jun; 26-Jun; } \\
\text { 04-Jul; 18-Jul; 26-Jul; 07-Aug; 14-Aug; 27-Aug; 05-Sep; 16-Sep; } \\
\text { 17-Sep; 30-Sep; 16-Oct }\end{array}$ & $\begin{array}{l}\text { 27-Apr; 04-May; 11-May; 21-May; 28-May; 31-May; 11-Jun; 18-Jun; } \\
\text { 27-Jun; 04-Jul; 13-Jul; 20-Jul; 27-Jul; 06-Aug; 16-Aug; 23-Aug; } \\
\text { 03-Sep; 20-Sep; 04-Oct; 19-Oct }\end{array}$ \\
\hline 2019 & $\begin{array}{l}\text { 06-May; 21-May; 30-May; 05-Jun; 13-Jun; 14-Jun; 19-Jun; 27-Jun; } \\
\text { 01-Jul; 10-Jul; 22-Jul; 01-Aug; 09-Aug; 21-Aug; 03- Sep; 11-Sep; } \\
\text { 21-Sep; 07-Oct; 14-Oct; 22-Oct }\end{array}$ & $\begin{array}{l}\text { 30-Apr; 07-May; 13-May; 21-May; 31-May; 07-Jun; 14-Jun; 20-Jun; } \\
\text { 28-Jun; 08-Jul; 16-Jul; 23-Jul; 29-Jul; 02-Aug; 09-Aug; 23-Aug; } \\
\text { 29-Aug; 05-Sep; 13-Sep; 26-Sep; 15-Oct }\end{array}$ \\
\hline
\end{tabular}

TABLE 2 | Species frequency (number of samples where the species was present $\mathrm{N}$ and expressed as the percentage of the total number of samples of samples where native coccinellid species occurred $\left(N_{\text {total }}\right)$ and species abundance (average number of individuals per 100 sweeps \pm SE) in samples where the native species occurred $\left(N_{\text {total }}\right)$.

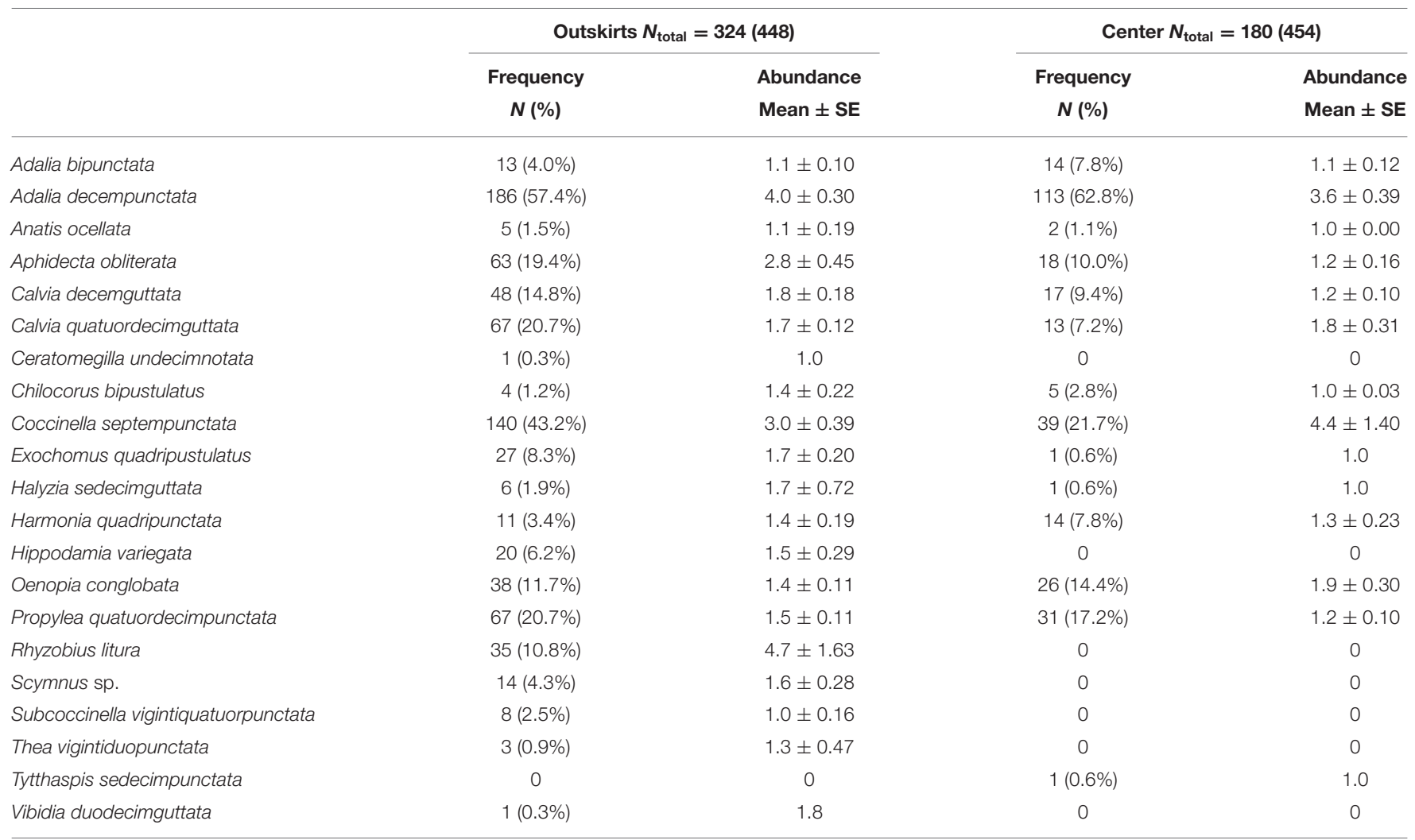

In parentheses: The total number of samples collected, including samples where no native coccinellids were present.

All species (regardless of their trophic specialization) were used to calculate the Shannon index describing species composition: Shannon index of diversity, $\mathrm{H}_{0}$, calculated as $\mathrm{H}_{0}=$ $\Sigma\left(\mathrm{pi}^{*} \ln (\mathrm{pi})\right)$, where pi is the proportion of the total number of captured individuals of species $i$.

To compare the frequency and abundance of species, the results were transformed into $z$-scores. The values of characteristics (i) and (ii) were standardized by transformation to $z$-scores, which is the distance of a count from the mean value in standard deviation units. $Z$-scores were calculated using the formula $\mathrm{z}=(\mathrm{x}-\mathrm{m}) / \mathrm{s}$, where $\mathrm{x}$ is the arithmetic mean of the values of characteristics (i) or (ii) on each sampling occasion, $\mathrm{m}$ are the values of characteristics (i) or (ii) on each sampling occasion and $s$ is the standard deviation of characteristics (i) or (ii) on each sampling occasion. 


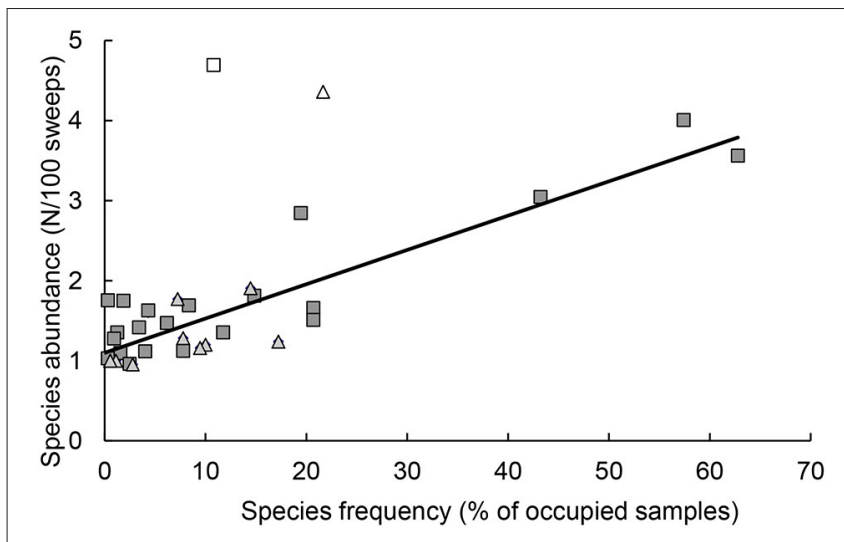

FIGURE 2 | Relationship between the two characteristics of the presence of coccinellid species, species abundance (average number of individuals per 100 sweeps) and species frequency (the percentage of samples in which the species was found). Each symbol represents one species of coccinellid, in the species composition in the outskirts $(\boldsymbol{\square})$ and center $(\boldsymbol{\Lambda})$. Hollow symbols: outliers not included in the calculation of regression ( $\square$ ), Rhyzobius litura $(\Delta)$, Coccinella septempunctata. Regression: $y=0.0155 x+1.1192, R^{2}=0.7944$, $n=32, P<0.001$.

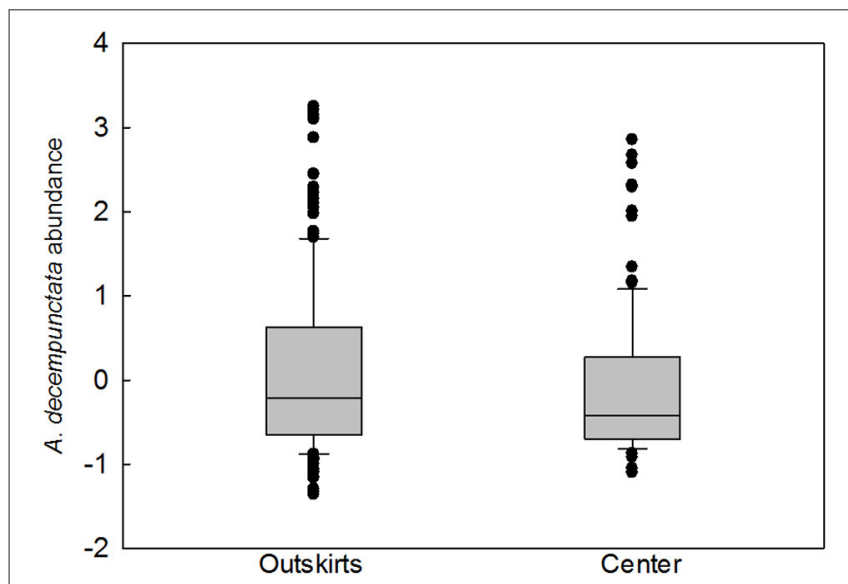

FIGURE 3 | The difference in abundance (number of individuals per 100 sweeps transformed as z scores) of Adalia decempunctata in the outskirts and in the center $\left(P_{M W}=0.050, U=11931.000\right)$. The graph plots the median and the 10th, 25th, 75th, and 90th percentiles as vertical boxes with error bars and outliers (dots).

The differences between means were tested by $t$-test or, when the normality test failed, by the Mann-Whitney (MW) test. To test for the difference in species occurrence in the outskirts vs. centers, a $t$-test was used for paired values, where the response variable was characteristic (i) (in angular transformation). The relationship between variables was fitted by a linear regression of $\mathrm{y}=\mathrm{ax}+\mathrm{b}$. All calculations were performed using SigmaStat 3.5 software (Systat Software Inc, 2006).

\section{RESULTS}

The frequency of samples containing native species was higher in outskirts (324 samples out of a total of 448 samples collected,

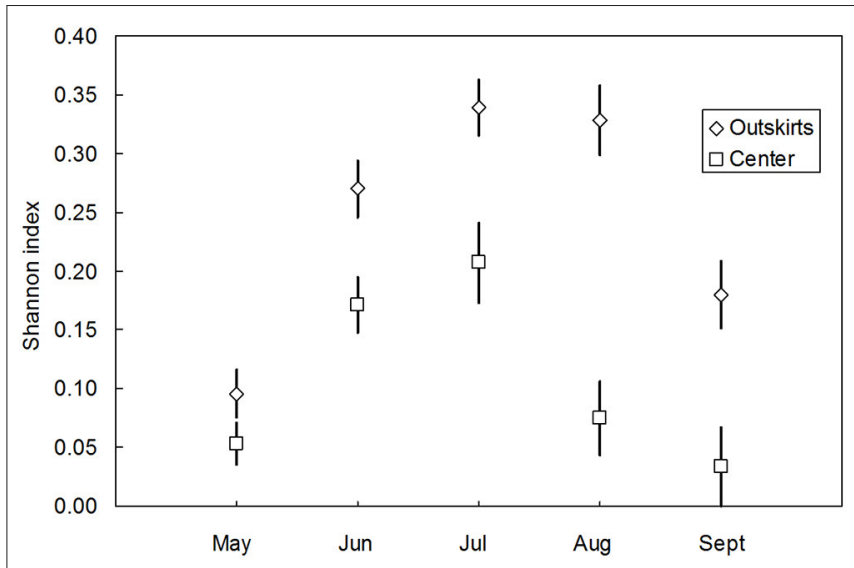

FIGURE 4 | Species diversity (mean Shannon index $\mathrm{H}_{0} \pm \mathrm{SE}$ ) over the course of the vegetative season (May-September) of coccinellid communities in the outskirts and center (pooled data from 2016-2019). The differences throughout the vegetative season: May (Nsmall $=42$, Nbig $=54, \mathrm{U}=$ 1302.500, $\mathrm{P}_{\mathrm{MW}}=0.113$, N.S.), June (Nsmall $=62$, Nbig $=80, \mathrm{U}=3236.500$, $\mathrm{P}_{\mathrm{MW}}=0.006$ ), July (Nsmall $=46$, Nbig $=80, \mathrm{U}=2425.000, \mathrm{P}_{\mathrm{MW}}=0.003$ ), August (Nsmall $=21$, Nbig $=64, U=1082.000, P_{M W}<0.001$ ), and September (Nsmall $=9$, Nbig $\left.=46, U=292.500, P_{M W}=0.034\right)$.

i.e., $72 \%)$ than in the centers (180 samples out of a total of 454 samples collected, i.e., 40\%) (Table 2). A total of 2,761 adults, 1,909 in the outskirts, and 807 in the center, of 21 species of native coccinellids were found in the outskirts and center. Thirteen species were found in both areas, seven species were found only in the outskirts and were missing in the center, and one species was found only in the center and was missing in the outskirts (Table 2). Of the species found in both areas, most were more frequent in samples from the outskirts than in samples from the center: e.g., Coccinella septempunctata L. (found in $43 \%$ of samples from the outskirts and in $22 \%$ of samples from the center), followed by fewer species of Aphidecta obliterata (L.) (19 and 10\%, respectively), Calvia decemguttata (L.) (15 and 9\%), C. quatuordecimguttata (L.) (21 and 7\%), and Propylea quatuordecimpunctata (L.) (21 and 17\%). In contrast, Adalia decempunctata (L.) was more frequent in samples from the center than from the outskirts (63 and 57\%), similar to Adalia bipunctata (L.) (8 and 4\%), Harmonia quadripunctata (Pontoppidan) (8 and 3\%), and Oenopia conglobata (L.) (14 and 12\%). Some species were found at low frequencies in the outskirts and center: Anatis ocellata (L.) (2 and 1\%), Chilocorus bipustulatus (L.) (1 and 3\%), and Halyzia sedecimguttata (L.) (2 and 1\%). Of the species missing from the center, Rhyzobius litura (Fabr.) (11\%) and Hippodamia variegata (Goeze) (6\%) were moderately abundant in the outskirts. In species present in both areas, abundance (characteristic ii) was greater in the outskirts in eight species (Adalia decempunctata, Anatis ocellata, Aphidecta obliterata, Calvia decemguttata, Chilocorus bipustulatus, Exochomus quadripustulatus (L.), Halyzia sedecimguttata, Harmonia quadripunctata), equal in both areas in one species (Adalia bipunctata), and greater in the center in three species (Calvia quatuordecimguttata, Coccinella septempunctata, Oenopia conglobata). A significant difference in 
species presence between outskirts and center was found only in A. decempunctata: the frequency (characteristic i) in the outskirts and center populations did not differ significantly (results not shown), and only abundance (characteristic ii) was significantly higher in the outskirts than in center populations (Figure 3).

Communities of coccinellids from the outskirts were richer in species (containing 20 species) than communities from the center (13 species). The presence of species in the communities of both areas (characteristic i) differed significantly $[t$ (paired values) $=$ $2,513, n=21, P<0.05]$. The species diversity of communities in the outskirts was higher than that in the center. Expressed as the Shannon index $\left(\mathrm{H}_{0}\right)$, the differences were significant in individual months except during May (Figure 4) and over the entire vegetative season $($ Nsmall $=180, \mathrm{Nbig}=324, \mathrm{U}$ $\left.=41907.000, \mathrm{P}_{\mathrm{MW}}<0.001\right)$. In the center, $A$. decempunctata and C. septempunctata significantly dominated the other species (Table 1).

\section{DISCUSSION}

The urban area (center), compared to outskirts, appears at first glance as an environment hostile to coccinellids. This is especially true in agglomerations where most of the area of the center is impervious, covered with buildings or paved roads, and without urban green spaces. However, some cities, including Prague, are less hostile to coccinellids because of continuous green spaces (parks, gardens) and tree lines planted on the impervious surfaces of the streets. Coccinellids live in these small areas of urban green spaces, often in high concentrations (Honek et al., 2017; Rocha et al., 2018). A factor that positively affects the aggregation of coccinellids in the city is the restriction of urban green areas to small areas, whereas populations outside the city would be evenly scattered over a large area instead of being concentrated. The urban environment per se may favorably affect the living conditions of coccinellids. One positive effect may be the temperate microclimate of the center and the smaller difference between day and night temperatures in the urban area than in the outskirts (Bonan, 2002). Additionally, the aphid abundance in urban tree stands may be higher than that in stands growing in the country, probably due to stress, which makes host trees less resistant to aphids (Fluckiger and Braun, 1999; Mackos-Iwaszko et al., 2015).

Despite the potential positive effects of urbanization, in this study, the coccinellid communities of the center were less speciesrich and less abundant than the communities of the outskirts.

The mechanism of the effects of urbanization on the abundance of native coccinellids can only be speculated. If there is a regular dispersion of native species from the outskirts to the center, then the absence or low frequency of some species may be caused by spatial isolation of Tilia stands in the center and the distance from source populations of native coccinellid species in the outskirts. Dispersions that manifested in the center of Prague

\section{REFERENCES}

Bonan, G. (2002). Ecological Climatology: Concept and Application. Cambridge: Cambridge University Press. p. 678. were observed in C. septempunctata. In the 1980s, they occurred regularly in late July when the adults flew to hibernation sites after the end of the period of mass reproduction in crop fields (Honek, 1989). Significant flight activity was also found in A. bipunctata, A. decempunctata, and H. quadripunctata (Honek, 1977), but its causes, timing, duration, and distance were not established.

The abundance of native coccinellids can be also negatively affected by the invasive Harmonia axyridis (Roy et al., 2012; Brown et al., 2015; Kenis et al., 2017; Masetti et al., 2018; Zaviezo et al., 2019). The extent of this negative effect depends on the species of native coccinellid (Honek et al., 2019a; Sloggett, 2021) and on the abundance of $H$. axyridis (Honek et al., 2018a, 2019b). If the occurrence of $H$. axyridis and its effects on native species differ, this invasive species could significantly affect differences in the presence and abundance of native coccinellids. The available data do not allow verification of this effect, as long-term records of the frequency of native coccinellids and $H$. axyridis are not yet available (Honek et al., 2020).

It can be concluded that the urban environment negatively affected coccinellid communities. The negative effect manifested even though the Prague agglomeration is relatively small $(\sim 1$ million inhabitants) and, in the center, impervious surfaces take only approximately three quarters of the surface area. To evaluate the impact of urbanization on coccinellid communities in general, it is necessary to gather more data on cities that have different sizes and different proportions of built-up areas than those in the center of Prague.

\section{DATA AVAILABILITY STATEMENT}

The original contributions presented in the study are included in the article/supplementary material, further inquiries can be directed to the corresponding author.

\section{AUTHOR CONTRIBUTIONS}

JS and AH designed the experiments, collected data, analyzed the data, and performed the statistical analyses. ZM coordinate all work. All authors wrote and edited the manuscript.

\section{FUNDING}

This work was supported by the program VES19 INTER-COST No. MSMT-15739/2019-6 (LTC19011; MŠMT ČR).

\section{ACKNOWLEDGMENTS}

We thank Ms. Helena Uhlí̌ová, Jana Kohoutová, and Hana Smutná for their excellent technical assistance. We thank also Ing. Kateřina Křižová for her help with upgrade of the map (Figure 1). 
Ceballos, G., Ehrlich, P. R., and Dirzo, R. (2017). Biological annihilation via the ongoing sixth mass extinction signaled by vertebrate population losses and declines. Proc. Natl. Acad. Sci. U.S.A. 114, E6089-E6096. doi: $10.1073 /$ pnas.1704949114

Cepelová, N., Kalusová, V., and Lososová, Z (2017). Effects of settlement size, urban heat island and habitat type on urbanplant biodiversity. Landsc. Urban Plan. 159, 15-22. doi: 10.1016/j.landurbplan.2016. 11.004

Fluckiger, W., and Braun, S. (1999). Stress factors of urban trees and their relevance for vigour and predisposition for parasite attacks. Acta Horticulturae 496, 325-334. doi: 10.17660/ActaHortic.1999.496.40

Goddard, M. A., Dougill, A. J., and Benton, T. G. (2010). Scaling up from gardens: biodiversity conservation in urban environments. Trends Ecol. Evol. 25, 90-98. doi: $10.1016 / j . t r e e .2009 .07 .016$

Greyvenstein, B., Botha, M., van den Berg, J., and Siebert, S. J. (2021). Level of urbanization and habitat type, and not patch size, influence predacious arthropod diversity patterns of urban grasslands in South Africa. Biodiversitas 22, 4078-4094. doi: 10.13057/biodiv/d220957

Hallmann, C. A., Sorg, M., Jongejans, E., Siepel, H., Hofland, N., Schwan, H., et al. (2017). More than 75 percent decline over 27 years in total flying insect biomass in protected areas. PLoS ONE 12:e0185809. doi: 10.1371/journal.pone.0185809

Hodek, I., van Emden, H. F., and Honek, A. (2012). Ecology and Behaviour of the Ladybird Beetles (Coccinellidae). Chichester: Wiley-Blackwell.

Honek, A. (1977). Annual variation in the complex of aphid predators: investigation by light trap. Acta Entomol. Bohemoslov. 74, 345-348.

Honek, A. (1989). Overwintering and annual changes of abundance of Coccinella septempunctata in Czechoslovakia (Coleoptera, Coccinellidae). Acta Entomol. Bohemoslov. 86, 179-192.

Honek, A., Brabec, M., Martinkova, Z., Dixon, A. F. G., Pekár, S., and Skuhrovec, J. (2019b). Factors determining local and seasonal variation in abundance of Harmonia axyridis (Coleoptera: Coccinellidae) in Central Europe. Eur. J. Entomol. 116, 93-103. doi: 10.14411/eje.2019.011

Honek, A., Brown, P. M. J., Martinkova, Z., Skuhrovec, J., Brabec, M., Burgio, G., et al. (2020). Factors determining variation in colour morph frequencies in invasive Harmonia axyridis populations. Biol. Invasions. 22, 2049-2062. doi: 10.1007/s10530-020-02238-0

Honek, A., Dixon, A. F., Soares, A. O., Skuhrovec, J., and Martinkova, Z. (2017). Spatial and temporal changes in the abundance and compostion of ladybird (Coleoptera: Coccinellidae) communities. Curr. Opin. Insect Sci. 20, 61-67. doi: 10.1016/j.cois.2017.04.001

Honek, A., Martinkova, Z., Dixon, A. F. G., Skuhrovec, J., Roy, H. E., Brabec, M., et al. (2018a). Life cycle of Harmonia axyridis (Coleoptera: Coccinellidae) in central Europe. Biocontrology 63, 241-252. doi: 10.1007/s10526-017-9864-2

Honek, A., Martinkova, Z., Roy, H. E., Dixon, A. F. G., Skuhrovec, J., Pekar, S., et al. (2019a). Differences in the phenology of Harmonia axyridis and native coccinellids on plants in central Europe (Coleoptera: Coccinellidae). Environ. Entomol. 48, 80-87. doi: 10.1093/ee/nvy173

Honek, A., Martinková, Z., and Štrobach, J. (2018b). Effect of aphid abundance and urbanization on the abundance of Harmonia axyridis (Coleoptera: Coccinellidae). Eur. J. Entomol. 115, 703-707. doi: 10.14411/eje.2018.069

Honek, A., Skuhrovec, J., Martinkova, Z., Kulfan, J., Jauschova, T., and Zach, P. (2021). Warm mesoclimate advances the seasonal dynamics of Harmonia axyridis in urban habitats. Front. Ecol. Evol. 9:725397. doi: $10.3389 /$ fevo.2021.725397

Jones, E. L., and Leather, S. R. (2012). Invertebrates in urban areas: a review. Eur. J. Entomol. 109, 463-178. doi: 10.14411/eje.2012.060

Jouveau, S., Delaunay, M., Vignes-Lebbe, R., and Nattier, R. (2018). A multi-access identification key based on colour patterns in ladybirds (Coleoptera, Coccinellidae). ZooKeys 758, 55-73. doi: 10.3897/zookeys.75 8.22171

Kenis, M., Adriaens, T., Brown, P. M. J., Katsanis, A., San Martin, G., Branquart, E., et al. (2017). Assessing the ecological risk posed by a recently established invasive alien predator: Harmonia axyridis as a case study. BioControl 62, 341-354. doi: 10.1007/s10526-016-9764-x
Korányi, D., Szigeti, V., Mezofi, L., Kondorosy, E., and Markó, V. (2021). Urbanization alters the abundance and composition of predator communities and leads to aphid outbreaks on urban trees. Urban Ecosyst. 24, 571-586. doi: 10.1007/s11252-020-01061-8

Mackos-Iwaszko, E., Lubiarz, M., and Karczmarz, K. (2015). The impact of urban conditions on the occurrence of aphids on Acer platanoides L. Acta Scientiarum Polonorum - Hortorum Cultus 14, 189-207.

Masetti, A., Magagnoli, S., Lami, F., Lanzoni, A., and Burgio, G. (2018). Long term changes in the communities of native ladybirds in Northern Italy: impact of the invasive species Harmonia axyridis (Pallas). BioControl 63, 665-675. doi: 10.1007/s10526-018-9891-7

McGlynn, T. P., Meineke, E. K., Bahlai, C. A., Li, E., Hartop, E. A., Adams, B. J., and et al. (2019). Temperature accounts for the biodiversity of a hyperdiverse group of insects in urban Los Angeles. Proc. R. Soc. B 286:20191818. doi: $10.1098 /$ rspb.2019.1818

Meyer, S., Rusterholz, H. P., and Baur, B. (2020). Urbanisation and forest size affect the infestation rates and plant-galling arthropods and damage by herbivorous insects. Eur. J. Entomol. 117, 34-48. doi: 10.14411/eje.2020.004

Milanovic, M., Kühn, I., Pyšek, P., and Knapp, S. (2021). Functional diversity changes in native and alien urban flora over three centuries. Biol. Invasions 23, 2337-2353. doi: 10.1007/s10530-021-02509-4

Nedvěd, O. (2020). Ladybird beetles (Coccinellidae) of Central Europe. Praha: Academia. p. 303.

Rocha, E. A., Souza, E. N. F., Bleakley, L. A. D., Burley, C., Mott, J. L., RueGlutting, G., et al. (2018). Influence of urbanisation and plants on the diversity and abundance of aphids and their ladybird and hoverfly predators in domestic gardens. Eur. J. Entomol. 115, 140-149. doi: 10.14411/eje.2018.013

Roy, H. E., Adriaens, T., Isaac, N. B., Kenis, M., San Martin y Gomez, G., Onkelinx, T., et al. (2012). Invasive alien predator causes rapid declines of native European ladybirds. Divers. Distrib. 18, 717-725. doi: 10.1111/j.1472-4642.2012.00883.x

Sánchez-Bayo, F., and Wyckhuys, K. A. G. (2019). Worldwide decline of the entomofauna: a review of its drivers. Biol. Conserv. 232, 8-27. doi: 10.1016/j.biocon.2019.01.020

Sloggett, J. J. (2021). Aphidophagous ladybirds (Coleoptera: Coccinellidae) and climate change: a review. Insect Conserv. Diver. 14, 709-722. doi: 10.1111 /icad.12527

Systat Software Inc (2006). SigmaStat 3.5 for Windows. Point Richmond, CA. p. 844.

Wagner, D. L., Grames, E. M., Forister, M. L., Berenbaum, M. R., and Stopak, D. (2021). Insect decline in the anthropocene: death by a thousand cuts. Proc. Natl. Acad. Sci. U.S.A. 118:e2023989118. doi: 10.1073/pnas.2023989118

Zaviezo, T., Soares, A. O., and Grez, A. A. (2019). Interspecific exploitative competition between Harmonia axyridis and other coccinellids is stronger than intraspecific competition. Biol. Control 131, 62-68. doi: 10.1016/j.biocontrol.2018.12.008

Conflict of Interest: The authors declare that the research was conducted in the absence of any commercial or financial relationships that could be construed as a potential conflict of interest.

Publisher's Note: All claims expressed in this article are solely those of the authors and do not necessarily represent those of their affiliated organizations, or those of the publisher, the editors and the reviewers. Any product that may be evaluated in this article, or claim that may be made by its manufacturer, is not guaranteed or endorsed by the publisher.

Copyright (๑) 2021 Skuhrovec, Honek and Martinkova. This is an open-access article distributed under the terms of the Creative Commons Attribution License (CC BY). The use, distribution or reproduction in other forums is permitted, provided the original author(s) and the copyright owner(s) are credited and that the original publication in this journal is cited, in accordance with accepted academic practice. No use, distribution or reproduction is permitted which does not comply with these terms. 